Article

\title{
24-O-Ethylmanoalide, a Manoalide-related Sesterterpene from the Marine sponge Luffariella cf. variabilis
}

\author{
Anne Gauvin-Bialecki ${ }^{*}$, Maurice Aknin and Jacqueline Smadja
}

Université de la Réunion, Laboratoire de Chimie des Substances Naturelles et des Sciences des Aliments, 97 715, Saint-Denis, La Réunion, France

Author to whom correspondence should be addressed; E-mail: anne.bialecki@univ-reunion.fr; Tel: +262 2629381 97; Fax: +262 262938183.

Received: 4 November 2008; in revised form: 5 December 2008 / Accepted: 11 December 2008 / Published: 15 December 2008

\begin{abstract}
A new manoalide-related sesterterpene, 24-O-ethylmanoalide (3), was isolated from the Indian Ocean sponge Luffariella cf. variabilis, together with the known compounds manoalide (1), seco-manoalide, manoalide monoacetate and 24-O-methylmanoalide (2). The structure of compound 3 was elucidated by interpretation of its spectroscopic data.
\end{abstract}

Keywords: Luffariella cf. variabilis; Demospongiae, Manoalide-related sesterterpene, 24O-ethylmanoalide.

\section{Introduction}

Marine sponges of the family Thorectidae (e.g. Luffariella [1-15], Hyrtios [16, 17], Thorectandra [18], Fasciospongia [19-23], and Aplynopsis [24]) are known to be a rich source of novel bioactive sesterterpenoids. Some of them containing a $\gamma$-hydroxybutenolide moiety showed a strong antiinflammatory activity. Manoalide (1), for example, the first sesterterpene to be reported from the Palauan sponge Luffariella variabilis by De Silva and Scheuer [1], has been extensively investigated as a potent inhibitor of phospholipase $\mathrm{A}_{2}\left(\mathrm{PLA}_{2}\right)$ [25-33]. Subsequently, many related metabolites with $\mathrm{PLA}_{2}$ inhibitory activity were reported [4, 25, 34-39]. In the course of our search for biologically 
active compounds from Indian Ocean marine organisms, our chemical investigation of a sponge from Mayotte Island belonging to the genus Luffariella, yielded manoalide (1) together with the known seco-manoalide [2], manoalide monoacetate [18], and 24-O-methylmanoalide (2) [13], as well as a new constituent which we have named 24-O-ethylmanoalide (3). In this paper, we describe the isolation and structure determination of compound 3.

\section{Results and Discussion}

The $\mathrm{MeOH}-\mathrm{CHCl}_{3}$ extract of Luffariella cf. variabilis was subjected to solvent partitioning, as outlined in the Experimental section. The hexane fraction was repeatedly fractionated by silica gel column chromatography, followed by normal phase HPLC to afford manoalide monoacetate, 24-Omethylmanoalide (2) and 24-O-ethylmanoalide (3). The $\mathrm{CCl}_{4}$ and $\mathrm{CHCl}_{3}$ fractions were combined and chromatographed on a silica gel column to furnish manoalide (1) and seco-manoalide. The latter was further purified by normal phase HPLC. The known compounds manoalide (1), seco-manoalide, manoalide monoacetate and 24-O-methylmanoalide (2) were identified through comparison of their physical data (NMR and EIMS) with published information [1-3, 13, 16, 18].

Compound 3 was obtained as a colorless glass. The IR spectrum contained three bands at 3410, 1790 and $1762 \mathrm{~cm}^{-1}$, typical of a $\gamma$-hydroxybutenolide moiety, and a band at $1098 \mathrm{~cm}^{-1}$ supporting the presence of an ether group. The EIMS showed a molecular peak at $m / z 444$. This datum together with its ${ }^{1} \mathrm{H}$ - and ${ }^{13} \mathrm{C}$-NMR spectra (Table 1 ) suggested the molecular formula $\mathrm{C}_{27} \mathrm{H}_{40} \mathrm{O}_{5}$. The mass spectrum showed an intense peak at $\mathrm{m} / \mathrm{z} 137$ and fragments ions at $\mathrm{m} / \mathrm{z} 121,107$ and 95 derived from the $\mathrm{m} / \mathrm{z}$ 137, implying the presence of the alkylated cyclohexenyl end group $\mathrm{C}_{10} \mathrm{H}_{17}$ commonly generated by manoalide-related sesterterpenes [18]. The ${ }^{1} \mathrm{H}$ - and ${ }^{13} \mathrm{C}$-NMR of 3 were almost identical with those of manoalide (1). However, they showed the characteristic signals of an additional ethoxy group [ $\delta_{\mathrm{H}} 3.55$, $3.83(2 \mathrm{H}, \mathrm{m}, \mathrm{H}-26), \delta_{\mathrm{H}} 1.23,1.24$ (3H, t, $\left.J=7.0 \mathrm{~Hz}, \mathrm{H}-27\right), \delta_{\mathrm{C}} 64.0,64.3$ (C-26), and $\delta_{\mathrm{C}} 15.3,15.4$ (C27)]. The ether linkage between $\mathrm{C}-24$ and $\mathrm{C}-26$ was suggested by the ${ }^{13} \mathrm{C}-\mathrm{NMR}$ chemical shift of $\mathrm{C}-24$ which resonated at a lower field $\left(\delta_{\mathrm{C}} 97.1,97.2\right)$ than the C-24 of (1) bearing an hydroxyl group $\left(\delta_{\mathrm{C}}\right.$ 91.2, 91.5). These data suggested structure 3 for 24-O-ethylmanoalide (Figure 1 ). Besides, pairs of two signals due to the same carbons or protons were detected in the ${ }^{1} \mathrm{H}$ - and ${ }^{13} \mathrm{C}-\mathrm{NMR}$ spectra of $\mathbf{3}$ as similar to the signals of manoalide [16], which are ascribable to a mixture of stereoisomers. Compound 3 includes three asymmetric carbon atoms; C-4, C-24 and C-25. The axial nature of C-4 i.e. its $R$ configuration, was deduced from its coupling constants to the C-5 protons (10.5, 3.4 Hz) [1]. C-24 in 3 was also presumed to be an $R$-configuration. Indeed, the relative configuration between $\mathrm{H}-4$ and $\mathrm{H}-24$ was established to be trans on the basis of the similarity of chemical shifts of H-4, H-5, H-6 and H-24 in 3 with those of $24 R-O$-methylmanoalide and not 24S-O-methylmanoalide [13]. Therefore it was deduced that $\mathbf{3}$ is a mixture of C-25 epimers with $R$-configuration at C-4 and C-24.

It is interesting to note that compounds $\mathbf{2}$ and $\mathbf{3}$ may be suspected to be artifacts due to experimental procedure. Manoalide is indeed a hemiacetal and its extraction under some particular conditions - as shown in Figure 1 - would be expected to produce compounds $\mathbf{2}$ and $\mathbf{3}$. If the conversion of $\mathbf{1}$ into 2 may be explained by the use of $\mathrm{MeOH}$ in the process of extraction [13], however the conversion of $\mathbf{1}$ into 3 requiring the use of $\mathrm{EtOH} / \mathrm{H}^{+}$remains unexplained. In the same way, in a previous report by 
Zhou and Molinski [14], manoalide (1) was presumed to be precursor of 24-O-propylmanoalide (4) (Figure 1), a manoalide derivative isolated from the Palauan sponge Luffariella variabilis.

Table 1. NMR Spectroscopic Data $\left(\mathrm{CDCl}_{3}\right)$ for 24-O-ethylmanoalide (3) ${ }^{a}$.

\begin{tabular}{|c|c|c|}
\hline position & $\delta_{C}$ & $\delta_{\mathrm{H}}(\mathrm{J}, \mathrm{Hz})$ \\
\hline 1 & $170.3,170.4$ & \\
\hline 2 & $117.5,118.4$ & $6.02,6.19 \mathrm{~s}$ \\
\hline 3 & $167.4,167.7$ & \\
\hline 4 & $62.3,63.2$ & $4.78,4.86 \mathrm{dd}(3.4,10.5)$ \\
\hline 5 & $28.8,29.1$ & $2.20 \mathrm{~m}$ \\
\hline 6 & $120.6,120.8$ & $5.66 \mathrm{~m}$ \\
\hline 7 & 136.8, 137.1 & \\
\hline 8 & 32.7 & $2.10 \mathrm{~m}$ \\
\hline 9 & 26.1 & $2.10 \mathrm{~m}$ \\
\hline 10 & 122.9 & $5.12 \mathrm{t}(6.1)$ \\
\hline 11 & 137.1 & \\
\hline 12 & 40.3 & $2.00 \mathrm{~m}$ \\
\hline 13 & 27.9 & $2.00 \mathrm{~m}$ \\
\hline 14 & 136.9 & \\
\hline 15 & 127.1 & \\
\hline 16 & 32.8 & $1.88 \mathrm{t}(6.2)$ \\
\hline 17 & 19.6 & $1.53 \mathrm{~m}$ \\
\hline 18 & 39.9 & $1.39 \mathrm{~m}$ \\
\hline 19 & 35.0 & \\
\hline 20 & 28.7 & $0.97 \mathrm{~s}$ \\
\hline 21 & 28.7 & $0.97 \mathrm{~s}$ \\
\hline 22 & 19.9 & $1.58 \mathrm{~s}$ \\
\hline 23 & 16.1 & $1.62 \mathrm{~s}$ \\
\hline 24 & $97.1,97.2$ & $4.89,4.92 \mathrm{~s}$ \\
\hline 25 & $97.1,97.7$ & $6.09,6.23 \mathrm{~s}$ \\
\hline 26 & $64.0,64.3$ & 3.55, $3.83 \mathrm{~m}$ \\
\hline 27 & $15.3,15.4$ & $1.23,1.24 \mathrm{t}(7.0)$ \\
\hline
\end{tabular}

However, according to the authors, the conditions of the process of extraction, partition and separation applied could not justify the conversion of $\mathbf{1}$ into $\mathbf{4}$. Thus, on the basis of the above results, we suggest that 24-O-ethylmanoalide (3) and 24-O-propylmanoalide (4) be considered as "true" metabolites produced by a biosynthetic pathway, rather than artifacts arising from the isolation procedure. 
Figure 1. Possible chemical conversion of 1 into 2, 3 and 4.

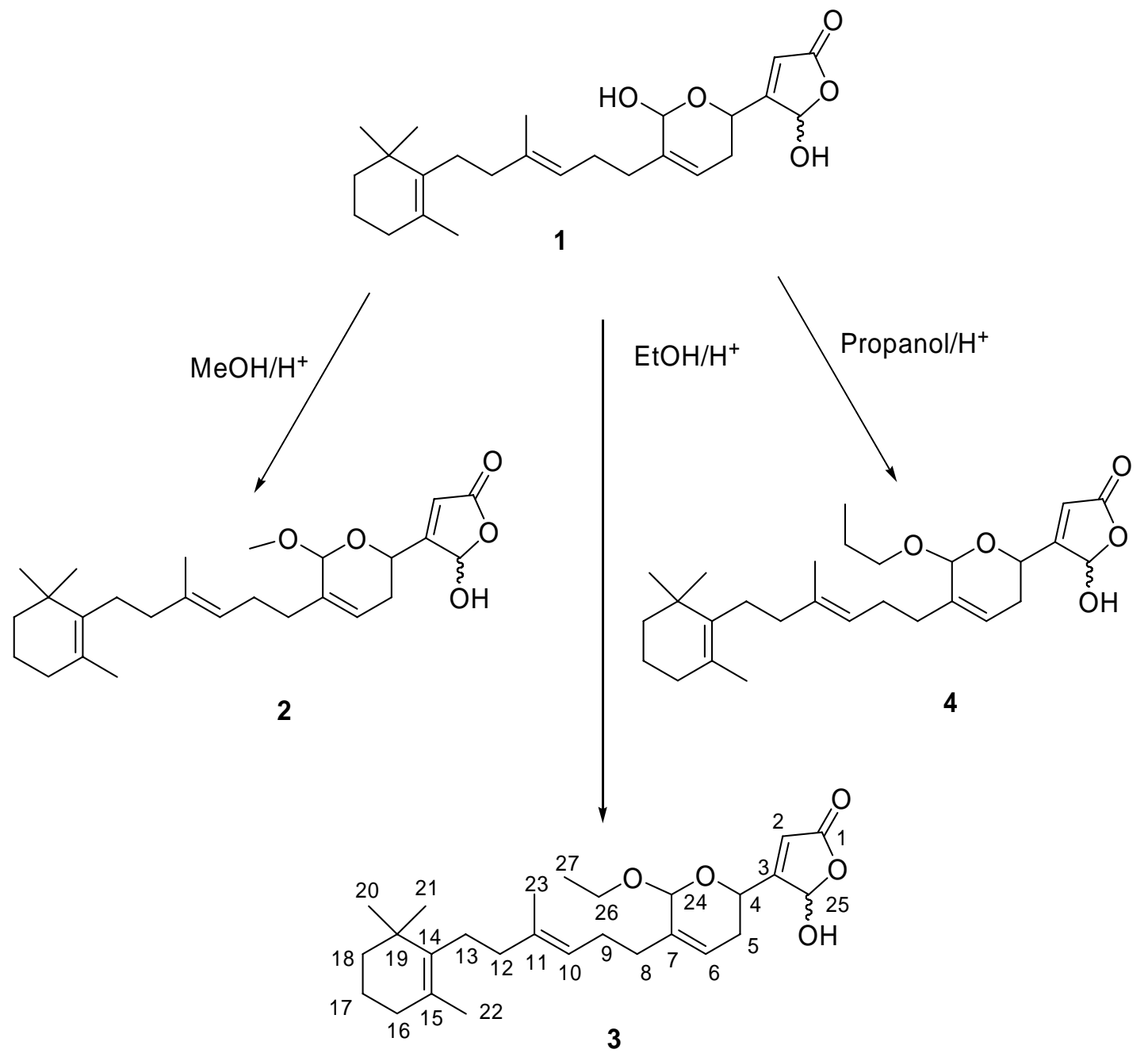

\section{Experimental}

\section{General}

Optical rotations were measured on a Perkin-Elmer 341 polarimeter. IR spectra were determined on a Perkin-Elmer 1600 FT-IR spectrometer. ${ }^{1} \mathrm{H}-(400 \mathrm{MHz})$ and ${ }^{13} \mathrm{C}-(100 \mathrm{MHz}) \mathrm{NMR}$ spectra were recorded on a Brucker $\mathrm{AMX}-400$, in $\mathrm{CDCl}_{3}$, with TMS as internal standard. Chemical shifts were reported in ppm and coupling constants $(J)$ were reported in Hz. EI mass spectra were obtained on a Jeol AX-500 mass spectrometer. HPLC was performed on a Spectraseries P100 equipped with a differential refractometer (Thermoseparation products - Refractomonitor). A Merck Lichrospher Si-60 column $(25 \mathrm{~cm} \times 10 \mathrm{~mm}$ i.d.) was used.

\section{Animal material}

The sponge Luffariella cf. variabilis (order Dictyoceratida, family Thorectidae) collected off Mayotte Island (Indian Ocean), in November 1995, was kept frozen until used. The material was 
identified by Dr N. Boury-Esnault (Station Marine d'Endoume - Marseille - France) and Pr P. Bergquist (School of Biological Sciences - Auckland - New Zealand). A voucher sample AGL-297M, has been deposited at the Laboratoire de Chimie des Substances Naturelles et des Sciences des Aliments (University of Reunion Island - France).

\section{Extraction and Isolation}

Frozen sponge tissue (1,343 g dry weight after extraction) was cut up and homogenized in a Waring-blender in $\mathrm{MeOH} / \mathrm{CHCl}_{3}$ (1:2). After filtration, the solvent was removed under reduced pressure to give the crude material (33.4 g), which was successively partitioned between equal volumes of aqueous $\mathrm{MeOH}$, percentage adjusted to produced a biphasic solution, and a solvent series of $n$-hexane (yield $5.71 \mathrm{~g}$ ), $\mathrm{CCl}_{4}$ (yield $11.95 \mathrm{~g}$ ) and $\mathrm{CHCl}_{3}$ (yield $7.44 \mathrm{~g}$ ). The remaining $\mathrm{H}_{2} \mathrm{O}$ soluble were extracted but did not contain any compounds of interest. A portion of the $n$-hexane fraction (2.98 g) was repeatedly subjected to silica gel columns using eluents of increasing polarity from 5\% EtOAc in $n$-hexane to $10 \%$ EtOAc in $n$-hexane, to afford a mixture of manoalide monoacetate, 24- $O$-methylmanaolide (2) and 24-O-ethylmanaolide (3). The resulting material was purified by semi-preparative HPLC over normal phase silica with hexane/EtOAc (7.5:2.5) to yield pure manoalide monoacetate (18 mg, 0.0026\%, dry wt), 2 (13 mg, 0.0019\%) and 3 (19 mg, 0.0027\%). $\mathrm{CCl}_{4}$ and $\mathrm{CHCl}_{3}$ solubles were combined on the basis of TLC, and a $4.38 \mathrm{~g}$ portion was fractionated by silica gel column chromatography eluted with $n$-hexane/EtOAc using a step gradient of increasing EtOAc (9:1 to 7:3) to afford pure manaolide (1) (99 mg, 0.033\%) and impure seco-manoalide. Final purification via HPLC using Si gel column with $n$-hexane/EtOAc (2:3) gave pure seco-manoalide (76 mg, 0.025\%).

24-O-ethylmanoalide (3): colourless glass; $[\alpha]^{25}{ }_{\mathrm{D}}+63^{\circ}\left(c\right.$ 0.5, $\left.\mathrm{CHCl}_{3}\right)$; IR $\left(\mathrm{CHCl}_{3}\right) v_{\max } 3410,2925$, 1790, 1762, 1098, $1040 \mathrm{~cm}^{-1}$; ${ }^{1} \mathrm{H}$ - and ${ }^{13} \mathrm{C}-\mathrm{NMR}$, see Table 1 ; EI mass spectrum $\mathrm{m} / \mathrm{z} 444[\mathrm{M}]^{+}(22)$, 426 (3), 398 (9), 380 (2), 261 (5), 203 (4), 177 (6), 137 (100), 123 (12), 121 (12), 107 (9), 95 (26), 81 (22).

\section{Acknowledgements}

This research was supported by the Regional Council of Reunion Island.

\section{References}

1. De Silva, E.D.; Scheuer, P.J. Manoalide, an antibiotic sesterterpenoid from the marine sponge Luffariella variabilis (Polejaeff). Tetrahedron Lett. 1980, 21, 1611-1614.

2. De Silva, E.D.; Scheuer, P.J. Three new sesterterpenoid antibiotics from the marine sponge Luffariella variabilis (Polejaeff). Tetrahedron Lett. 1981, 22, 3147-3150.

3. Kernan, M.R.; Faulkner, D.J.; Jacobs, R.S. The luffariellins, novel anti-inflammatory sesterterpenes of chemotaxonomic importance from the marine sponge Luffariella variabils. J. Org. Chem. 1987, 52, 3081-3083. 
4. Albizati, K.F.; Holman, T.; Faulkner, D.J.; Glaser, K.B.; Jacobs, R.S. Luffariellolide, an antiinflammatory sesterterpene from the marine sponge Luffariella sp. Experientia 1987, 43, 949-950.

5. Kernan, M.R.; Faulkner, D.J.; Parkanyi, L.; Clardy, J.; De Carvalho, M.S.; Jacobs, R.S. Luffolide, a novel anti-inflammatory terpene from the sponge Luffariella sp. Experientia 1989, 45, 388-390.

6. König, G.M.; Wright, A.D.; Sticher, O. Four new antibacterial sesterterpenes from a marine sponge of the genus Luffariella. J. Nat. Prod. 1992, 55, 174-178.

7. Potts, B.C.M.; Capon, R.J.; Faulkner, D.J. Luffalactone and (4E,6E)-dehydromanoalide from the sponge Luffariella variabilis. J. Org. Chem. 1992, 57, 2965-2967.

8. Butler, M.S.; Capon, R.J. The luffarins (A-Z), novel terpenes from an australian marine sponge, Luffariella geomatrica. Aust. J. Chem. 1992, 45, 1705-1743.

9. Tsuda, M.; Shigemori, H.; Ishibashi, M.; Sasaki, T.; Kobayashi, J. Luffariolides A-E, new cytotoxic sesterterpenes from the okinawan marine sponge Luffariella sp. J. Org. Chem. 1992, 57, 3503-3507.

10. Kobayashi, J.; Zeng, C.M.; Ishibashi, M.; Sasaki, T. Luffariolides F and G, new manoalide derivatives from the okinawan marine sponge Luffariella sp. J. Nat. Prod. 1993, 56, 436-439.

11. Reddy, M.V.R.; Harper, M.K.; Faulkner, D.J. Luffasterols A-C, 9,11-secosterols from the Palauan sponge Luffariella sp. J. Nat. Prod. 1997, 60, 41-43.

12. Tsuda, M.; Endo, T., Mikami, Y., Fromont, J.; Kobayashi, J. Luffariolides H and J, new sesterterpenes from a marine sponge Luffariella. J. Nat. Prod. 2002, 65, 1507-1508.

13. Namikoshi, M.; Suzuki, S.; Meguro, S.; Nagai, H.; Koike, Y.; Kitazawa, A.; Kobayashi, H.; Oda, T.; Yamada, J. Manoalide derivatives from a marine sponge Luffariella sp. collected in Palau. Fish. Sci. 2004, 70, 152-158.

14. Zhou, G.X.; Molinski, T.F. Manoalide derivatives from a sponge, Luffariella sp. J. Asian Nat. Prod. Res. 2006, 8, 15-20.

15. Ettinger-Epstein, P.; Motti, C.A.; De Nys, R.; Wright, A.D.; Battershill, C.N.; Tapiolas, D. M. Acetylated sesterterpenes from the Great Barrier reef sponge Luffariella variabilis. J. Nat. Prod. 2007, 70, 648-651.

16. Kobayashi, M.; Okamoto, T.; Hayashi, K.; Yokoyama, N.; Sasaki, T.; Kitagawa, I. Marine natural products. XXXII. Absolute configurations of C-4 of the manoalide family, biologically active sesterterpenes from the marine sponge Hyrtios erecta. Chem. Pharm. Bull. 1994, 42, 265-270.

17. Bourguet-Kondracki, M.L.; Debitus, C.; Guyot, M. Biologically active sesterterpenes from a new caledonian marine sponge Hyrtios sp. J. Chem. Res. 1996, 192-193.

18. Cambie, R.C.; Craw, P.A.; Bergquist, P.R.; Karuso, P. Chemistry of sponges, III. Manoalide monoacetate and thorectolide monoacetate, two new seterterpenoids from Thorectandra excavatus. J. Nat. Prod. 1988, 51, 331-334.

19. De Rosa, S.; De Stefano, S.; Zavodnik, N. Cacospongionolide: a new antitumoral sesterterpene, from the marine sponge Cacospongia mollior. J. Org. Chem. 1988, 53, 5020-5023.

20. Montagnac, A.; Païs, M.; Debitus, C. Fasciospongides A, B, and C, new manoalide derivatives from the sponge Fasciospongia sp. J. Nat. Prod. 1994, 57, 186-190. 
21. De Rosa, S.; Crispino, A.; De Giulio, A.; Iodice, C.; Pronzato, R.; Zavodnik, N. Cacospongionolide B, a new sesterterpene from the sponge Fasciospongia cavernosa. J. Nat. Prod. 1995, 58, 1776-1780.

22. De Rosa, S.; Crispino, A.; De Giulio, A.; Iodice, C.; Tommonaro, G. Cavernosolide, a new sesterterpene from a Tyrrhenian sponge. J. Nat. Prod. 1997, 60, 844-846.

23. De Rosa, S.; Carbonelli, S. Two new luffarin derivatives from the Adriatic sea sponge Fasciospongia cavernosa. Tetrahedron 2006, 61, 2845-2849.

24. Ueoka, R.; Nakao, Y.; Fujii, S.; Van Soest, R.W.M.; Matsunaga, S. Aplysinoplides A-C, cytotoxic sesterterpnes from the marine sponge Aplysinopsis digitata. J. Nat. Prod. 2008, 71, 1089-1091.

25. Soriente, A.; De Rosa, M.; Scettri, A.; Sodano, G.; Terencio, M.C.; Paya, M.; Alcaraz, M.J. Manoalide. Curr. Med. Chem. 1999, 6, 415-431.

26. De Freitas, J.C.; Blankmeier, L.A.; Jacobs, R.S. In vitro inactivation of the neurotoxic action of $\beta$ bungarotoxin by the marine natural product, manoalide. Experientia 1984, 40, 864-865.

27. Lombardo D.; Dennis, E.A. Cobra venom phospholipase A2 inhibition by manoalide. J. Biol. Chem. 1985, 260, 7234-7240.

28. Glaser K.B.; Jacobs, R.S. Molecular pharmacology of manoalide. Inactivation of bee venom phospholipase A2. Biochem. Pharm. 1986, 35, 449-453.

29. Glaser K.B.; Jacobs, R.S. Inactivation of bee venom phospholipase A2 by manoalide. A model based on the reactivity of manoalide with amino acids and peptide sequences. Biochem. Pharmac. 1987, 36, 2079-2086.

30. Bennett, C.F.; Mong, S.; Clarke, M.A.; Kruse, L.I., Crooke, S.T. Differential effects of manoalide on secreted and intracellular phospholipases. Biochem. Pharm. 1987, 36, 733-740.

31. Glaser, K.B.; De Carvalho, M.S.; Jacobs, R.S.; Kernan, M.R.; Faulkner, D.J. Manoalide: structure-activity studies and definition of the pharmacophore for phospholipase $\mathrm{A}_{2}$ inactivation. Mol. Pharmacol. 1989, 36, 782-788.

32. Jacobson, P.B.; Marshall, L.A.; Sung, A.; Jacobs, R.S. Inactivation of human synovial fluid phospholipase $\mathrm{A}_{2}$ by the marine natural product, manoalide. Biochem. Pharm.1990, 39, 15571564.

33. Ortiz, A. R.; Pisabarro, M. T.; Gago, F. Molecular model of the interaction of bee venom phospholipase $\mathrm{A}_{2}$ with manoalide. J. Med. Chem. 1993, 36, 1866-1879.

34. Deems, R.A.; Lombardo, D.; Morgan, B.P.; Mihelich, E.D.; Dennis, E.A. The inhibition of phospholipase $\mathrm{A}_{2}$ by manoalide and manoalide analogues. Biochim. Biophys. Acta 1987, 917, 258-268.

35. Reynolds, L.J.; Morgan, B. P.; Hite, G.A.; Mihelich, E.D.; Dennis, E.A. Phospholipase $\mathrm{A}_{2}$ inhibition and modification by manoalogue. J. Am. Chem. Soc. 1988, 110, 5172-5177.

36. Potts, B.C.M.; Faukner, D.J. Phospholipase $\mathrm{A}_{2}$ inhibitors from marine organisms. J. Nat. Prod. 1992, 55, 1701-1717.

37. Reynolds, L.J.; Mihelich, E.D.; Dennis, E.A. Inhibition of venom phospholipase $\mathrm{A}_{2}$ by manoalide and manoalogue. J. Biol. Chem. 1991, 266, 16512-16517. 
38. Potts, B.C.M.; Faulkner, D.J.; De Carvalho, M.S.; Jacobs, R.S. Chemical mechanism of inactivation of bee venom phospholipase $\mathrm{A}_{2}$ by the marine natural products manoalide, luffariellolide, and scalaradial. J. Am. Chem. Soc. 1992, 114, 5093-5100.

39. De Rosa, M.; Giordano, S., Scettri, A., Sodano, G., Soriente, A., Pastor, P.G.; Alcaraz, M.J.; Paya, M. Synthesis and comparison of the antiinflammatory activity of manoalide and cacospongionolide B analogues. J. Med. Chem. 1998, 41, 3232-3238.

Sample Availability: Not avaiable.

(c) 2008 by the authors; licensee Molecular Diversity Preservation International, Basel, Switzerland. This article is an open-access article distributed under the terms and conditions of the Creative Commons Attribution license (http://creativecommons.org/licenses/by/3.0/). 